\title{
Interleukin-2 production of lymphocytes in food sensitive atopic dermatitis
}

\author{
Hiroatsu Agata, Naomi Kondo, Osamu Fukutomi, Shinji Shinoda, Tadao Orii
}

\begin{abstract}
The proliferative responses of peripheral blood mononuclear cells (PBMC) to food antigens in 22 patients with food sensitive atopic dermatitis were significantly higher than the responses of healthy children and food sensitive children with immediate symptoms. Moreover, the activity of interleukin-2 (IL-2) in supernatants of food antigen stimulated PBMC cultures from patients with atopic dermatitis was significantly higher than that in healthy children and food sensitive children with immediate symptoms. The activity of IL-2 in culture supernatants of separated cell populations stimulated with food antigens from patients with atopic dermatitis and healthy children was investigated. The activity of IL-2 in supernatants of food antigen stimulated $T$ cell cultures could be detected in patients with atopic dermatitis but not in healthy children. These results suggest that the increased IL-2 production after food antigen stimulation is due to increased $\mathbf{T}$ cell activity in food sensitive atopic dermatitis.
\end{abstract}

Food allergy clearly seems to play an aggravating part in some patients with atopic dermatitis, and the significance of $\operatorname{IgE}$ in the pathogenesis had been discussed. ${ }^{2}$ Patients with atopic dermatitis caused by food allergens do not always have food specific IgE antibodies. Wraith et al have reported that $36 \%$ of foods causing 'non-immediate' symptoms give a negative radioallergosorbent test (RAST). ${ }^{3}$ There is no clear correlation between the quantities of specific IgE antibodies and the nature and the severity of allergic symptoms, and patients may retain IgE antibodies for many years after they have ceased to suffer symptoms. Moreover, it is certain that atopic patients have abnormal responses in cell mediated immunity. ${ }^{4-6}$ There have been some reports on proliferative responses of $\mathrm{PBMC}^{7-9}$ and interleukin-2 (IL-2) production of inhaled antigen stimulated PBMC from allergic patients. ${ }^{10} 11$ However, little has been reported on IL-2 production of food antigen stimulated PBMC from food sensitive patients. The aim of the present study was to find the proliferative responses of PBMC and T cells to food antigens and the IL-2 production of PBMC and T cells stimulated with food antigens in patients with atopic dermatitis who were sensitive to food allergens.

Subjects and methods

SUBJECTS

Twenty two patients with atopic dermatitis were studied. Twelve were selected on the basis of clinical history and food challenges as being sensitive to hens' egg and 10 were selected as being sensitive to cows' milk. The 12 patients with atopic dermatitis who were sensitive to hens' egg ranged in age from 4 months- 11 years (mean 2.5 years) and the 10 patients with atopic dermatitis were sensitive to cows' milk ranged in age from 4 months-10 years (mean 4.9 years). Food challenges were performed generally in the double blind, placebo controlled manner of Bock et $a l,,^{12}$ and in an open manner if there was a clear cut history of major allergic skin symptoms after ingestion of a specific food or if there was a chance of systemic anaphylaxis. Diagnosis of atopic dermatitis was defined by the criteria of Hanifin. ${ }^{13}$ Cutaneous manifestations of most patients with atopic dermatitis appeared after two hours or more (usually within 48 hours) after hens' egg or cows' milk ingestion. The control group included 11 nonatopic healthy children without hens' egg or cows' milk sensitivity, ranging in age from 1-10 years (mean 4.2 years) (control group I), and seven hens' egg sensitive and nine cows' milk sensitive patients ranging in age from 11 months-13 years (mean 3.7 years) with urticaria, angio-oedema, acute gastroenteritis, and asthma (immediate symptoms) that appeared within one hour (usually within 15 minutes) after hens' egg or cows' milk ingestion (control group II). The RAST scores for hens' egg or cows' milk, proliferative responses of PBMC to food antigens, and IL-2 production of PBMC stimulated with food antigens were examined when diseases were diagnosed.

\section{RAST}

The RAST was performed as recommended by the Phadebas RAST test kit (Pharmacia). ${ }^{14}$ Hens' egg and cows' milk discs were supplied by Pharmacia. RAST results were scored 0 to $4+$ by comparison with serially diluted reference sera (Pharmacia) graded $A$ to $D$ (that is, a serum $\angle \mathrm{D}=0$, between $\mathrm{D}$ and $\mathrm{C}=1+$, and $>\mathrm{A}=4+$ ). RAST scores of $2+, 3+$, and $4+$ were recorded as positive.

\section{CELL SEPARATION AND CULTURE}

Blood was taken into preservative free heparin and was separated by gradient centrifugation with the use of Ficoll-Paque (Pharmacia). PBMC were harvested from the interface and washed three times in phosphate buffered saline. To remove adherent cells, $2-5 \times 10^{7} \mathrm{PBMC}$ were incubated in $20 \mathrm{ml}$ of culture medium consisting of Roswell Park Memorial Institute (RPMI) 
medium 1640 supplemented with $15 \%$ pooled human $A B$ positive serum, penicillin $(100 \mathrm{U} / \mathrm{ml})$, streptomycin $(100 \mu \mathrm{g} / \mathrm{ml})$, and L-glutamine ( $2 \mathrm{mM}$ ) in $75 \mathrm{~cm}^{3}$ tissue culture flasks (Falcon) for 2-3 hours at $37^{\circ} \mathrm{C}$. Non-adherent cells were recovered and were separated into a $T$ cell enriched population and a $B$ cell enriched population by the rosetting method with neuraminidase treated sheep red blood cells (SRBC), after which they were subjected to centrifugation over Ficoll-Paque ${ }^{15}$ and a nylon wool column. ${ }^{16}$ The rosetted cells were collected from the bottom, recovered by lysis of the $\mathrm{SRBC}$ in an isotonic ammonium chloride buffer for 10 minutes at $4^{\circ} \mathrm{C}$, passed through the column, and washed three times with phosphate buffered saline. These cells were mainly $\mathrm{T}$ cells (CD3+>98\%). Non-rosetted cells were collected from the interface and passed through the column. They were used as B cells $(72 \%$ $\mathrm{CD} 20+, 2 \% \mathrm{CD} 3+$, and $2 \% \mathrm{CD} 14+)$. The adherent cells were harvested by a rubber policeman and washed three times with phosphate buffered saline. PBMC, T cells with adherent cells, and B cells with adherent cells were separately cultured at $1 \times 10^{6} / \mathrm{ml}$ in RPMI 1640 culture medium supplemented with $15 \%$ pooled human $A B$ positive serum. Cultures were performed in triplicate at $0.2 \mathrm{ml}$ per well in round bottomed microtest plates or culture test tubes with or without food antigens (A/S Nunc) at $37^{\circ} \mathrm{C}$ in a humidified atmosphere containing $5 \%$ carbon dioxide for $3-5$ days. $^{7}$ Food antigens, ovalbumin (Wako Junyaku), and bovine serum albumin (Wako Junyaku) were separately diluted in culture medium and were added in final concentrations of 0.25 $\mu \mathrm{g} / \mathrm{ml}, 2.5 \mu \mathrm{g} / \mathrm{ml}$, and $25 \mu \mathrm{g} / \mathrm{ml}$, respectively.

DNA synthesis was measured by adding 0.5 $\mu \mathrm{Ci}$ tritiated $\left({ }^{3} \mathrm{H}\right)$-thymidine per well four hours before harvesting onto glass fibre filters. ${ }^{3} \mathrm{H}$-thymidine incorporation was measured by liquid scintillation counting as counts per minute (cpm) and the results were expressed as the mean of triplicate. To compare responses between individuals, we expressed the results as a stimulation index (SI) using the following formula:

$\mathrm{SI}=\frac{\mathrm{cpm} \text { in cultures stimulated with food antigens }}{\mathrm{cpm} \text { in unstimulated cultures }}$
On the other hand, culture supernatants in the culture test tubes were spun to remove cells after three days and stored frozen at $-40^{\circ} \mathrm{C}$ until measurement of the activity of IL-2.

MEASUREMENT OF THE ACTIVITY OF IL-2

The biological activity of IL-2 was determined by proliferation of cells from a mouse $\mathrm{T}$ cell line, NKC-3, which was highly dependent on IL-2 activity for growth. NKC-3 was a gift from Takeda Chemical Industries Co Ltd. Cells were cultured at $6 \times 10^{5} / \mathrm{ml}$ in RPMI 1640 culture medium with $20 \%$ heat inactivated fetal calf serum in round bottomed microtest plates in triplicate at $50 \mu \mathrm{l}$ per well. Cultures were performed with $50 \mu \mathrm{l}$ culture supernatant and $50 \mu \mathrm{l}$ RPMI 1640 culture medium in a humidified atmosphere with $5 \%$ carbon dioxide for 24 hours, and were then pulsed with $0.5 \mu \mathrm{Ci}$ ${ }^{3} \mathrm{H}$-thymidine per well four hours before harvesting. To compare responses between individuals we expressed the results as a SI using the following formula:

cpm in cultures with supernatants of food antigen stimulated PBMC

$\mathrm{SI}=\frac{\text { antigen stimulated PBMC }}{\mathrm{cpm} \text { in cultures with supernatants of }}$ unstimulated PBMC

\section{STATISTICS}

Student's $t$ test was used for the comparison of SI in different groups. The comparison of RAST scores was assessed by $\chi^{2}$ analysis.

\section{Results}

RAST SCORES

The results of RAST scores, proliferative responses of PBMC and the activity of IL-2 for control group I, control group II, and patients with atopic dermatitis are presented in tables 1 and 2. The RAST values for hens' egg of patients with atopic dermatitis with hens' eggs sensitivity were significantly $(p<0.01)$ lower than the RAST values of control group II. Although the RAST values for cows' milk of patients with atopic dermatitis with cows' milk sensitivity tended to be lower than the RAST

Table 1 Results of RAST scores for hens' egg sensitivity, proliferative responses of PBMC to ovalbumin, and the activity of IL-2 in culture supernatants of PBMC stimulated with ovalbumin for control group I, control group II, and patients with atopic dermatitis

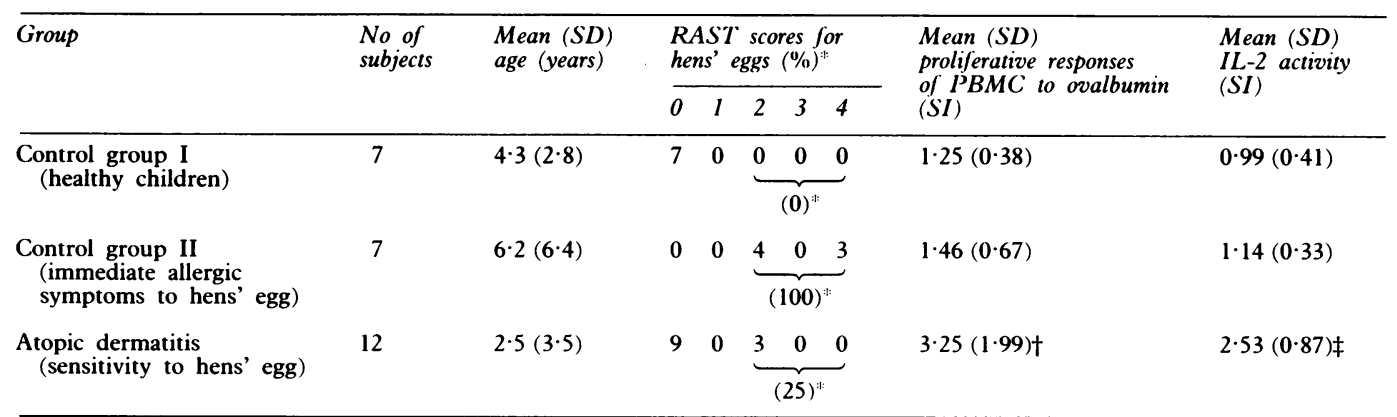

Cases with positive RAST score/total cases.

†The proliferative responses of PBMC to ovalbumin in patients with atopic dermatitis sensitive to hens' egg were significantly higher than control group I $(p<0.005)$ and II $(p<0.01)$.

†Activity of IL-2 in supernatants of ovalbumin or stimulated PBMC cultures from patients with atopic dermatitis sensitive to hens' egg were significantly higher than control group I and II $(p<0 \cdot 005)$. 
Table 2 Results of RAST scores for cows' milk sensitivity, proliferative responses of PBMC to bovine serum albumin, and the activity of IL-2 in culture supernatants of PBMC stimulated with bovine serum albumin for control group $I$, control group II, and patients with atopic dermatitis

\begin{tabular}{|c|c|c|c|c|c|c|c|c|}
\hline \multirow[t]{2}{*}{ Group } & \multirow[t]{2}{*}{$\begin{array}{l}\text { No of } \\
\text { subjects }\end{array}$} & \multirow[t]{2}{*}{$\begin{array}{l}\text { Mean }(S D) \\
\text { age (years) }\end{array}$} & \multicolumn{4}{|c|}{$\begin{array}{l}\text { RAST scores for } \\
\text { cows' milk }(\%)^{*}\end{array}$} & \multirow{2}{*}{$\begin{array}{l}\text { Mean }(S D) \\
\text { proliferative responses } \\
\text { of PBMC to bovine } \\
\text { serum albumin }(S I)\end{array}$} & \multirow{2}{*}{$\begin{array}{l}\text { Mean }(S D) \\
I L-2 \text { activity } \\
(S I)\end{array}$} \\
\hline & & & 0 & 1 & 23 & 4 & & \\
\hline \multirow{2}{*}{$\begin{array}{l}\text { Control group I } \\
\text { (healthy children) }\end{array}$} & 4 & $4 \cdot 0(4 \cdot 2)$ & 2 & 2 & $\begin{array}{ll}0 & 0\end{array}$ & 0 & $1 \cdot 11(0 \cdot 30)$ & $0.83(0.81)$ \\
\hline & & & & & $(0)^{*}$ & & & \\
\hline \multirow{2}{*}{$\begin{array}{l}\text { Control group II } \\
\text { (immediate allergic } \\
\text { symptoms to cows' milk) }\end{array}$} & 9 & $1 \cdot 7(0.9)$ & 0 & 3 & 42 & 0 & $1 \cdot 12(0 \cdot 42)$ & $1.25(0.59)$ \\
\hline & & & & & $(67)^{*}$ & & & \\
\hline \multirow{2}{*}{$\begin{array}{l}\text { Atopic dermatitis } \\
\text { (sensitivity to cows' milk) }\end{array}$} & 10 & $4 \cdot 9(4 \cdot 0)$ & 7 & 0 & 21 & 0 & $2 \cdot 42(1 \cdot 24) \dagger$ & $3 \cdot 23(1 \cdot 49) \ddagger$ \\
\hline & & & & & $(30)^{*}$ & & & \\
\hline
\end{tabular}

${ }^{*}$ Cases with positive RAST score/total cases.

†The proliferative responses of PBMC to bovine serum albumin in patients with atopic dermatitis sensitive to cows' milk were significantly higher than control group I and II $(p<0.005)$.

†Activity of IL-2 in supernatants of bovine serum albumin stimulated PBMC cultures from patients with atopic dermatitis sensitive to cows' milk were significantly higher than control group I and II $(p<\mathbf{0} \cdot \mathbf{0 0 5})$.

values of control group II, there was no significant difference.

PROLIFERATIVE RESPONSES OF PBMC TO OVALBUMIN OR BOVINE SERUM ALBUMIN The proliferative responses of PBMC to ovalbumin in patients with atopic dermatitis who were sensitive to hens' egg were significantly higher than those of either control group I or control group II $(\mathrm{p}<0.005, \mathrm{p}<0.01$, respectively; table 1). Similar results were seen in cows' milk allergy, as shown in table 2 . The proliferative responses of PBMC to bovine serum albumin in patients with atopic dermatitis who were sensitive to cows' milk were significantly higher than those of either control group I or control group II ( $p<0.005$, respectively). These results suggest that the proliferative responses of PBMC to ovalbumin or bovine serum albumin have a significant value in patients with atopic dermatitis who are sensitive to hens' egg or cows' milk. We have previously reported such findings. ${ }^{7}$

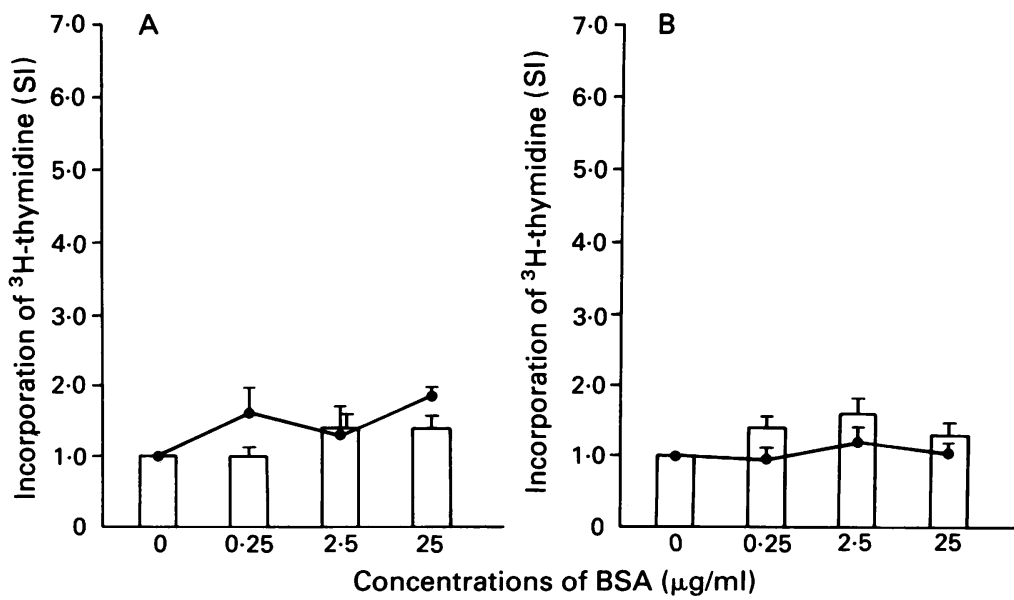

Figure 1 Proliferative responses of $T$ cells and $B$ cells to bovine serum albumin $(B S A)$, and $I L-2$ production in $B S A$ stimulated $T$ cell and $B$ cell cultures from a healthy child. $(A)$ The line indicates the proliferative responses of $T$ cells with adherent cells to BSA. The columns indicate the activity of $I L-2$ in culture supernatants of $B S A$ stimulated $T$ cells with adherent cells. $(B)$ The line indicates the proliferative responses of $B$ cells with adherent cells to $B S A$ The columns indicate the activity of $I L-2$ in culture supernatants of $B S A$ stimulated $B$ cells with adherent cells. Each value is the mean of triplicate and each bar indicates ISD.
IL-2 PRODUCTION IN OVALBUMIN OR BOVINE SERUM ALBUMIN STIMULATED PBMC CULTURES The activity of IL-2 in supernatants of ovalbumin stimulated PBMC cultures from patients with atopic dermatitis who were sensitive to hens' egg was significantly higher than that in either control group I or control group II $(p<0.005$, respectively; table 1 ). Similarly, the activity of IL-2 in supernatants of bovine serum albumin stimulated PBMC cultures from patients with atopic dermatitis who were sensitive to cows' milk was significantly higher than that in either control group I or control group II $(p<0.005$, respectively; table 2 ).

\section{IL-2 PRODUCTION IN OVALBUMIN OR BOVINE} SERUM ALBUMIN STIMULATED T CELL OR B CELL CULTURES

We investigated the proliferative responses of PBMC, T cells with adherent cells, and B cells with adherent cells to ovalbumin or bovine serum albumin and IL-2 activity of culture supernatants in two randomly selected patients whose clinical manifestations of atopic dermatitis were severe and in two age matched healthy children. One of the two patients with atopic dermatitis was sensitive to hens' egg and the other was sensitive to cows' milk. The proliferative responses of $T$ cells with adherent cells and $B$ cells with adherent cells to bovine serum albumin and IL-2 activity of culture supernatants from a healthy child who is not sensitive to cows' milk are shown in fig 1 . Both T cells with adherent cells and $B$ cells with adherent cells did not respond to bovine serum albumin. Furthermore, IL-2 activity could not be detected in culture supernatants of bovine serum albumin stimulated $T$ cells with adherent cells or B cells with adherent cells. The results for a patient with atopic dermatitis who is sensitive to cows' milk are shown in fig 2 . T cells with adherent cells responded to bovine serum albumin, whereas B cells with adherent cells did not respond. IL-2 activity could be detected in culture supernatants of bovine serum albumin stimulated $\mathrm{T}$ cells with adherent cells; however, it could not be detected in culture supernatants of bovine serum albumin stimulated B cells with 


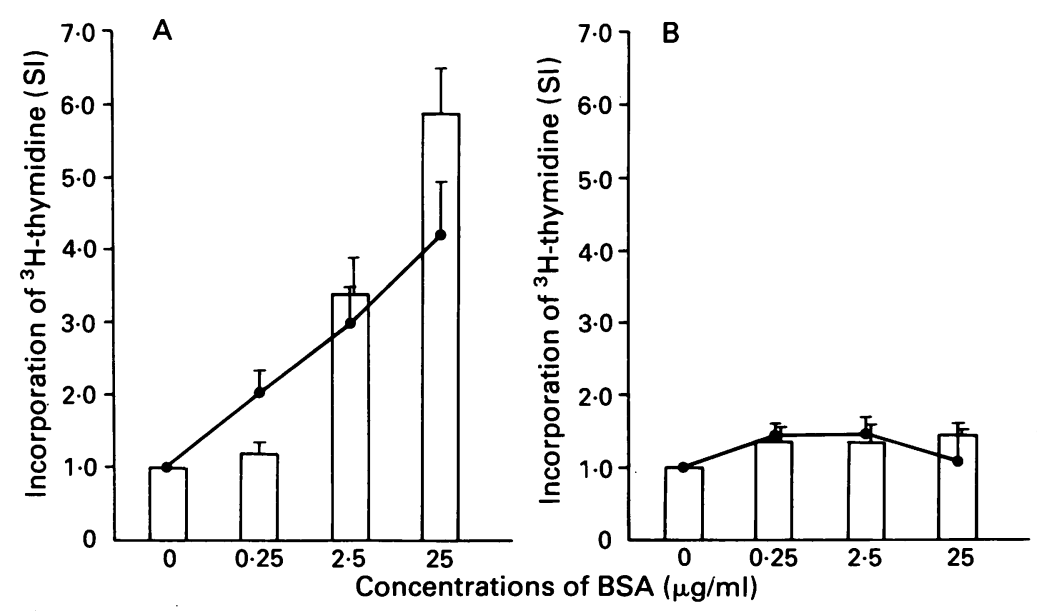

Figure 2 Proliferative responses of $T$ cells and $B$ cells to bovine serum albumin (BSA), and $I L-2$ production in $B S A$ stimulated $T$ cell and $B$ cell cultures from a patient with atopic dermatitis who is sensitive to cows' milk. (A) The line indicates the proliferative responses of $T$ cells with adherent cells to BSA. The columns indicate the activity of $I L-2$ in culture supernatants of BSA stimulated T cells with adherent cells. (B) The line indicates the proliferative responses of $B$ cells with adherent cells to $B S A$. The columns indicate the activity of IL-2 in culture supernatants of BSA stimulated B cells with adherent cells. Each value is the mean of triplicate and each bar indicates $I S D$.

adherent cells. These results suggest that IL-2 production was only recognised in culture supernatants of bovine serum albumin stimulated $T$ cells with adherent cells which had significantly responded to bovine serum albumin in a cows' milk sensitive patient with atopic dermatitis. The results of IL-2 activity in separated cell population cultures of a patient with atopic dermatitis with hens' egg sensitivity and a healthy child are shown in table 3 . The results shown in table 3 are the same as those in figs 1 and 2. Consequently, the increased IL-2 production after food antigen stimulation seemed to be due to increased $T$ cell activity.

\section{Discussion}

IL-2 was first recognised as a substance produced by $T$ cells that had the ability to help support normal T cell proliferation in tissue culture. ${ }^{17} 18$ Recently it was discovered that IL-2 promotes the proliferation of activated T cells ${ }^{19}$ as well as $B$ cells. ${ }^{20}{ }^{21}$ IL-2 acts by binding with IL-2 receptors on $T$ cells and $B$ cells, as well as natural killer cells. After antigen or mitogen activation of $T$ cells, the cells begin to express an IL-2 receptor that appears within the first several hours after activation. Maximum expression occurs two to three days later followed by a decline in IL-2 receptor expression. ${ }^{22}$ IL-2 production has generally been shown to be a function of OKT4+ T helper cells, ${ }^{23}$ although another report suggests that, when stimulated by concanavalin $\mathrm{A}, \mathrm{OKT}+8$ cells may also produce IL-2. ${ }^{24}$ Rawle $e t$ al have reported that IL-2 production was detected in supernatants of antigen $P_{1}$ stimulated $T$ cell cultures from Dermatophagoides pteronyssinus sensitive patients. ${ }^{10}$ In other studies, 'lymphocyte mitogenic factor' was reported in three day supernants of PBMC cultures of allergic patients proliferating in response to grass pollen. ${ }^{11}$ Mosmann et al have reported that mouse helper $T$ cell clones fall into two main groups (TH1 and $\mathrm{TH} 2$ ), defined primarily by differences in the pattern of lymphokines synthesised. ${ }^{25} 26$ TH1 clones synthesise IL-2, interferon $\gamma$, and lymphotoxin, whereas these lymphokines are not detectably expressed in TH2 clones. Conversely, only $\mathrm{TH} 2$ clones synthesise detectable amounts of IL-4 and IL-5. TH1 clones also cause effective delayed type hypersensitivity reactions. ${ }^{25} 26$

In this study, proliferative responses of both PBMC and $T$ cells to food antigens were recognised. Moreover, IL-2 production of PBMC and T cell cultures stimulated with food antigens was detected in patients with atopic dermatitis who were sensitive to food allergens. These results suggest that the increased IL-2 production after food antigen stimulation is due to increased $T$ cell activity in patients with atopic dermatitis who are sensitive to food allergens.

We are grateful to Central Research Division, Takeda Chemical Industries Ltd for supplying cells, NKC-3, and to Misses Yukiko Hirano, Ryo Takenaka, and Tsukako Kameyama for the culture Hirano, Ryo

1 Sampson HA. The role of food allergy and mediator release in atopic dermatitis (Jerome Glaser lectureship). $\mathcal{F}$ Allergy Clin Immunol 1988;81:635-45.

2 Hoffman DR, Yamamoto FY, Geller B, Haddad Z. Specific IgE antibodies in atopic eczema. $\mathcal{F}$ Allergy Clin Immunol 1975;55:256-67.

3 Wraith DG, Merrett J, Roth A, Yman L, Merrett TG. Recognition of food-allergic patients and their allergens by the RAST technique and clinical investigation. Clinical Allergy 1979;9:25-36.

4 Matloff SM, Kiselis IK, Rocklin RE. Reduced production of histamine-induced suppressor factor (HSF) by atopic mononuclear cells and decreased prostaglandin $\mathrm{E}_{2}$ output by HSF-stimulated atopic monocytes. $f$ Allergy Clin by HSF-stimulated atopic

5 Hwang K-C, Fikrig SM, Friedman HM, Gupta S. Autologous mixed lymphocyte reaction in man: VII. Autologous mixed lymphocyte reaction in patients with bronchial asthma, allergic rhinitis, and atopic dermatitis. Allergy 1983;38: 113-8.

6 Alam R, Rozniecki J, Salmaj K. A mononuclear cell derived histamine releasing factor (HRF) in asthmatic patients. Histamine release from basophils in vitro. Ann Allergy 1984;53:66-9.

7 Kondo N, Agata H, Fukutomi O, Motoyoshi F, Orii T. Lymphocyte responses to food antigens in patients with atopic dermatitis who are sensitive to foods. F Allergy Clin Immunol 1990;86:253-60.

Table 3 Results of proliferative responses and the activity of IL-2 in culture supernatants from separated cell populations stimulated with ovalbumin in a patient with atopic dermatitis and a healthy child

\begin{tabular}{|c|c|c|c|c|c|c|c|}
\hline & \multirow[t]{2}{*}{$\begin{array}{l}\text { Serum } I g E \\
(U / m l)\end{array}$} & \multirow{2}{*}{$\begin{array}{l}\text { RAST } \\
\text { scores for } \\
\text { hens' egg }\end{array}$} & \multicolumn{3}{|c|}{$\begin{array}{l}\text { Proliferative responses to } \\
\text { ovalbumin }(S I)\end{array}$} & \multicolumn{2}{|c|}{$\begin{array}{l}\text { IL-2 activity in } \\
\text { culture supernatants }(S I)\end{array}$} \\
\hline & & & $\begin{array}{l}\text { Unseparated } \\
\text { PBMC }\end{array}$ & $T+A d^{*}$ & $B+A d t$ & $T+A d^{*}$ & $B+A d t$ \\
\hline $\begin{array}{l}\text { Healthy child } \\
\text { Patient with atopic dermatitis } \\
\text { (sensitive to hens' egg) }\end{array}$ & $\begin{array}{r}38 \\
150\end{array}$ & $\begin{array}{l}0 \\
2\end{array}$ & $\begin{array}{l}1.63 \\
\text { ND }\end{array}$ & $\begin{array}{l}1 \cdot 63 \\
4 \cdot 30\end{array}$ & $\begin{array}{l}1.06 \\
1.01\end{array}$ & $\begin{array}{l}1 \cdot 21 \\
2 \cdot 68\end{array}$ & $\begin{array}{l}1 \cdot 37 \\
0 \cdot 81\end{array}$ \\
\hline
\end{tabular}

*T cells with adherent cells.

†B cells with adherent cells.

ND, not done. 
8 Van Sickle GJ, Powell GK, McDonald PJ, Goldblum RM. Milk- and soy protein-induced enterocolitis: evidence for lymphocyte sensitization to specific food proteins. Gastrolymphocyte sensitization to
enterology 1985;88:1915-21.

9 Gatien JG, Merler E, Colten HR. Allergy to ragweed antigen E: Effect of specific immunotherapy on the reactivity of human T lymphocytes in vitro. Clin Immunol Immunopathol 1975;4:32-7.

10 Rawle FC, Mitchell EB, Platts-Mills TAE. T cell responses to the major allergen from the house dust mite Dermatophagoides pteronyssinus, antigen- $P_{1}$ : comparison of patients with asthma, atopic dermatitis and perennial rhinitis. f Immunol 1984;133:195-201.

11 Maini RN, Dumonde DC, Faux JA, Hargreave FE, Pepys J. The production of lymphocyte mitogenic factor and migration-inhibition factor by antigen-stimulated lymphocytes of subjects with grass pollen allergy. Clin Exp Immunol 1971;9:449-65.

12 Bock SA, Sampson HA, Atkins FM, et al. Double-blind, placebo-controlled food challenge (DBPCFC) as an office procedure: a manual. $f$ Allergy Clin Immunol 1988;82: 986-97.

13 Hanifin JM. Atopic dermatitis. $\mathcal{f}$ Allergy Clin Immunol 1984;73:211-22.

14 Chua YY, Bremner K, Llobet JL, Kokubu HL, CollinsWilliams C. Diagnosis of food allergy by the radioallergosorbent test. $\mathcal{F}$ Allergy Clin Immunol 1976;58:477-82.

15 Spits H, Yssel H, Paliard X, Kastelein R, Figdor C, Vries JE. IL-4 inhibits IL-2-mediated induction of human lymphokine-activated killer cells, but not the generation of antigen-specific cytotoxic T lymphocytes in mixed leukocyte cultures. F Immunol 1988;141:29-36.

16 Handwerger BS, Schwartz RH. Separation of murine lymphoid cells using nylon wool columns: recovery of the
B cell-enriched population. Transplantation 1974;18:544-8. 17 Morgan DA, Ruscetti FW, Gallo R. Selective in vitro growth of T lymphocytes from normal human bone marrows. of T lymphocytes 1976;193:1007-8.

18 Gillis S, Smith KA. Long term culture of tumor-specific cytotoxic T cells. Nature 1977;268:154-6.

19 Smith KA. Interleukin 2. An Reo Immul 1984:2 319-33.

20 Zubler RH, Lowenthal JW, Erard F, Hashimoto N, Devos R, MacDonald HR. Activated B cells express receptors for, and proliferate in response to, pure interleukin 2. $\mathcal{J}$ Exp Med 1984;160:1170-83

21 Hashimoto N, Nabholz M, MacDonald HR, Zubler RH. Dissociation of interleukin 2-dependent and -independent B cell proliferation with monoclonal anti-interleukin 2 receptor antibody. Eur F Immunol 1986;16:317-20.

22 Waldmann TA. The structure, function and expression of interleukin-2 receptors on normal and malignant lymphocytes. Science 1986;232:727-32.

23 Reinherz EL, Kung PC, Breard JM, Goldstein G, Schlossman SF. T cell requirements for generation of helper factor(s) in man: analysis of the subsets involved. 7 Immunol 1980;124: 1883-7.

24 Luger TA, Smolen IS, Chused TM Steinberg AD Oppenheim JJ. Human lymphocytes with either the OKT4 or OKT8 phenotype produce interleukin 2 in culture. or OKT8 phenotype produce

25 Mosmann TR, Cherwinski H, Bond MW, Giedlin MA, Coffman RL. Two types of murine helper $T$ cell clone: 1 . Definition according to profiles of lymphokine activities .

26 Mosmann TR, Coffman RL. TH1 and TH2 cells: different patterns of lymphokine secretion lead to different functional properties. Ann Rev Immunol 1989;7:145-73. 